\title{
Effect of Fungicides and Storage Conditions on Postharvest Development of Citrus Black Spot and Survival of Guignardia citricarpa in Fruit Tissues
}

\author{
J. P. Agostini, Instituto Nacional de Técnologia Agropecúaria, Montecarlo, Misiones, Argentina; N. A. Peres and \\ S. J. Mackenzie, University of Florida, Gulf Coast Research and Education Center, Wimauma, FL 33598; \\ J. E. Adaskaveg, Department of Plant Pathology, University of California, Riverside 92521; and L. W. Timmer, Uni- \\ versity of Florida, Department of Plant Pathology, Citrus Research and Education Center, Lake Alfred 33850 USA
}

\begin{abstract}
Agostini, J. P., Peres, N. A., Mackenzie, S. J., Adaskaveg, J. E., and Timmer, L. W. 2006. Effect of fungicides and storage conditions on postharvest development of citrus black spot and survival of Guignardia citricarpa in fruit tissues. Plant Dis. 90:1419-1424.

Citrus black spot (CBS) is caused by Guignardia citricarpa, which incites lesions on citrus fruit and can induce fruit drop. Quiescent infections occur during the spring and summer, and symptoms appear at fruit maturity or after harvest. Thus, fruit from citrus areas affected by CBS represent a risk for introduction of this pathogen into new areas. The effects of preventive field fungicide programs, postharvest fungicide drenches, packinghouse fungicide applications, and storage temperatures on postharvest symptom development and viability of G. citricarpa in lesions were evaluated in five experiments on Murcott tangor, Valencia oranges, and lemons. Preventive field treatments and fruit storage at $8^{\circ} \mathrm{C}$ consistently reduced postharvest CBS development, whereas a postharvest fungicide drench or packinghouse treatment with fungicides had no effect on postharvest symptom development. In a separate experiment, postharvest appearance of symptoms was related to the percentage of fruit with symptoms at harvest. The preventive field fungicide program also consistently reduced the percentage of isolation of G. citricarpa from affected fruit, whereas storage temperature and packinghouse fungicide treatment gave variable results. The viability of the fungus declined with storage time of fruit after harvest, but $G$. citricarpa could still be readily isolated regardless of treatment. In another experiment, the viability of the fungus in detached fruit or peel was minimally affected by temperature or moisture during storage. The frequency of successful isolation declined with time, but G. citricarpa was still recovered frequently from symptomatic tissue at later times. The most effective means to reduce postharvest development of symptoms is through preventive application of fungicides during the fruit growing season and storage of harvested fruit at cold temperatures. None of the measures evaluated substantially reduced viability of G. citricarpa, and the pathogen would likely be introduced on symptomatic fruit from citrus areas with CBS.
\end{abstract}

Additional keywords: benzimidazole fungicides, fludioxonil, imazalil, Phyllosticta citricarpa, pyrimethanil

Citrus black spot (CBS), caused by Guignardia citricarpa Kiely, has become a serious, widespread problem for citrus production in South America (6,7,19). The disease is also common in Asia, South Africa, and Australia, but is not known to occur in North America or in Mediterranean citrus-growing areas $(13,18)$. Various types of symptoms may occur with CBS $(9,10,12,13)$. The hard spot symptom is a sunken lesion with black margins and gray centers that often bear pycnidia of the asexual stage of the G. citricarpa, Phyllos-

Corresponding author: L. W. Timmer

E-mail: 1wtimmer@ufl.edu

This research was partially supported by Project No. 5300-117 of the California Citrus Research Board.

Accepted for publication 20 June 2006.

DOI: 10.1094/PD-90-1419

(C) 2006 The American Phytopathological Society velop in the fall and winter. Conidia form in pycnidia on infected leaves and fruit and may serve for short-distance dispersal of the pathogen by rain splash. The fungus is most easily isolated from hard spot or virulent spot symptoms, but grows slowly and is often overrun in culture by fastergrowing saprophytes such as Colletotrichum gloeosporioides. Conducting Koch's postulates is difficult given the extended latent period of the fungus. It is uncertain whether the different symptom types are due to infection by different propagules, infection at various stages of fruit maturity, environmental factors, or some combination of these factors.

Due to the presence of CBS in many countries in the Southern Hemisphere, the European Community (EC) and the United States (U.S.) severely limit importation of fresh citrus fruit from those countries where the disease is present $(3,4)$. These regulations restrict potential market access for countries with CBS and reduce the availability of citrus fruit for consumers in the off-season in the Northern Hemisphere. Markets were available in the past in northern Europe, but those have been eliminated in recent years since the EC includes citrus-producing countries such as Spain and Italy. Thus, fruit from countries with CBS can no longer be shipped even to EC countries that produce no citrus.

Symptomless fruit from regions where CBS is present may develop symptoms during transport. Exposure of fruit to intense light and high temperatures speeds development of CBS symptoms $(5,22)$. In the protocol that allowed shipment of lemons from Argentina to the United States, samples from fruit lots for export were exposed to these conducive conditions prior to shipment to be sure they were free of CBS.

Various treatments have been explored to reduce the risk of introduction of CBS into countries that are currently free of this disease. Preharvest sprays of copper fungicides did not reduce the appearance of CBS symptoms after harvest (20). Preharvest sprays of benzimidazoles as well as postharvest applications of thiophanatemethyl were effective in delaying expression of CBS after harvest (17), but in other studies postharvest applications of thiabendazole did not reduce the development of CBS in storage after harvest $(1,2)$. Wax- 
ing and some postharvest fungicide treatments were found to reduce postharvest development of CBS in studies in Australia $(20,23)$. Korf et al. (11) found that postharvest treatments with guazatine, imazalil, hot water, or fruit waxes decreased the viability of the pathogen in CBS lesions and prevented reinfection of mature fruit by conidia produced in pycnidia on symptomatic fruit. Refrigeration of fruit greatly slowed, but did not prevent lesion development (11).

No studies have been conducted on the survival of the pathogen in whole fruit or detached peel under different conditions. Thus, there is little information on the potential of the infected fruit to serve as a source of inoculum for establishment of the pathogen in CBS-free countries.

The purpose of this study was to assess the effect of preventive field applications of fungicides, drench application of fungicides at harvest, application of registered and experimental fungicides in the packinghouse, and cold storage of fruit on development of CBS after harvest. In addition, the ability of G. citricarpa to survive in fruit and peel after harvest under various conditions was assessed.

\section{MATERIALS AND METHODS}

Effect of preharvest field fungicide applications, postharvest fungicide drenches, packinghouse fungicide applications, and storage temperatures. Five experiments were conducted using fruit of Murcott tangor (probable Citrus reticulata $\times C$. sinensis hybrid) for one experiment, and of Valencia orange (C. sinensis) and lemon (C. limon) in two experiments each in Misiones, Argentina. Fungicide treatments were applied as: (i) field application to trees during the main infection period in spring and summer, (ii) drench treatments immediately following harvest, and (iii) postharvest treatment of fruit in a commercial packinghouse. The effect of storage temperature at $8^{\circ} \mathrm{C}$ and ambient temperature $\left(18\right.$ to $\left.25^{\circ} \mathrm{C}\right)$ was also evaluated. The field spray program in the Murcott planting was: copper hydroxide (Champ $80 \mathrm{WP}$ at $3 \mathrm{~kg}$ ) applied on 25 September 2002; trifloxystrobin (Flint 50 at $0.1 \mathrm{~kg}$ ) + copper hydroxide on 1 November 2002, copper hydroxide on 18 December 2002, and trifloxystrobin + copper oxychloride (Caurofix at $3.0 \mathrm{~kg}$ ) on 31 January 2003. In the lemon (A) and (B) experiments, carbendazim (Carbendazim 50 SC at 1.2 liters) was applied on 18 September 2002 and trifloxstrobin + copper hydroxide on 1 November 2002. In the Valencia (A) and (B) experiments, carbendazim + copper oxychloride were applied on 13 September 2002, pyraclostrobin (Comet at 0.2 liters) + mancozeb (Mancozeb 80 at 2.0 liters) on 15 October 2002, carbendazim on 8 December 2002, pyraclostrobin + copper oxychloride on 7 January 2003, and again on 17 March 2003. All rates are per 1,000 liters and included petroleum oil at 5.0 liters, and the commercial products and rates were the same as where first mentioned.

In the Murcott, Valencia (A), and lemon (A) experiments, fruit lots were collected arbitrarily from those treatments receiving field applications described above and from nonsprayed control trees. Fruit from the Murcott grove were harvested on 2 July 2003 and from the Valencia (A) and lemon (A) groves on 10 November 2003. Half of each fruit lot was dipped in an aqueous mixture of benomyl (Benosem) at $1,000 \mu \mathrm{g} / \mathrm{ml}$, fosetyl-Al (Aliette $80 \mathrm{WP}$ ) at $3,200 \mu \mathrm{g} / \mathrm{ml}$, and 2,4-D (Citone) at 10 $\mu \mathrm{g} / \mathrm{ml}$ immediately after harvest. After transport to a commercial packinghouse in L. N. de Alem, Misiones, Argentina, sublots of fruit were treated with one of the following products in a commercial packing line: (i) aqueous solution of a water wax (tristearyl citrate, Citrowax 75) only, (ii) fludioxonil (Graduate, Syngenta) at $1,000 \mu \mathrm{g} / \mathrm{ml}$, (iii) pyrimethanil (Scala 400SC, Janssen Pharmaceutica) at 1,000 $\mu \mathrm{g} / \mathrm{ml}$, (iv) pyrimethanil at $1,000 \mu \mathrm{g} / \mathrm{ml}+$ imazalil (Janssen Pharmaceutica) at 1,000 $\mu \mathrm{g} / \mathrm{ml}$, or (v) a commercial treatment of imazalil (Deccozil 80, Elf Atochem) at $2,500 \mu \mathrm{g} / \mathrm{ml}+$ thiabendazole (Tecto MSD Agrovet, Merck and Co.) at 5,000 $\mu \mathrm{g} / \mathrm{ml}+$ 2,4-D (Citone) at $500 \mu \mathrm{g} / \mathrm{ml}$. All treatments included water wax to prevent dehydration of fruit during storage. Prior to application of the fungicides and wax, all fruit were passed through a chlorinated bath. Half of the fruit from each of the above treatments was stored loose in boxes and in the dark at $8^{\circ} \mathrm{C}$ and the other half was stored at ambient temperature and exposed to ambient light for 10 to $12 \mathrm{~h}$ per day.

All fruit used in the above experiments were free of symptoms at the time of harvest. The percentage of fruit with symptoms in the sprayed and nonsprayed field plots was determined at harvest by examining 100 fruit in each plot to evaluate the efficacy of the preharvest field fungicide program.

In the Valencia (B) and lemon (B) experiments, only fruit from trees sprayed with the preharvest fungicide programs were utilized for evaluation of postharvest treatments. Fruit from the Valencia (B) grove were harvested on 4 September 2003, and fruit from the lemon (B) grove were harvested on 10 November 2003. Half of the fruit in the Valencia (B) experiment received the benomyl drench treatment at harvest as described above. In the lemon (B) experiment, none of the fruit received the benomyl drench treatment. In both experiments, half of the fruit was stored at ambient temperature and half at $8^{\circ} \mathrm{C}$ (lemon A) or $12^{\circ} \mathrm{C}$ (lemon B).

Stored fruit from all experiments were inspected for CBS symptoms 49 days after harvest, and the percent showing any symptom of CBS was determined. De- pending on the experiment, 64 to 471 fruit were examined for each lot of fruit with each combination of treatments. The effect of field fungicide treatment, postharvest benomyl drench, packinghouse fungicide application, and storage temperature on CBS incidence as well as two-way interactions among main effects was determined using analysis of variance. Data were transformed to $\log (\%$ disease +1$)$ prior to analysis to normalize the variances and eliminate multiplicative interactions. For experiments Murcott, Valencia (A), and Lemon (A), 40 different combinations of the field, benomyl drench, storage temperature, and postharvest fungicide treatments were examined. Each combination was represented once. Using this experimental design, each individual field, benomyl drench, and storage temperature treatment was replicated 20 times; and each postharvest fungicide application was replicated 8 times. Main effects and twoway interactions were examined for these experiments using an analysis of variance model where the residual variance term consisted of all three- and four-way interactions. For the Valencia (B) experiment, in which field treatment was not evaluated, 20 combinations of benomyl drench, storage temperature, and postharvest fungicide application were examined, and each combination was represented once. Using this experimental design, each benomyl drench and storage temperature treatment was replicated 10 times. Postharvest fungicide treatments were replicated 4 times. Main effects and two-way interactions were examined for these experiments using an analysis of variance model in which the residual variance term consisted of the three-way interaction among main effects. For Lemon (B), in which only storage temperature and postharvest fungicide treatments were examined, storage treatments were replicated 5 times and postharvest fungicide applications twice within an experimental design in which 10 combinations of storage temperature and postharvest fungicide treatment were represented once. In this experiment, only main effects were examined using analysis of variance, with the residual error term consisting of the two-way interaction of main effects. Mean separations of treatments were made using Fisher's protected least significant difference test $(P \leq 0.05)$. Data were presented as actual means rather than backtransformed values.

Fungal isolations were made from arbitrarily selected fruit with hard spot or other CBS symptoms in the Murcott, Valencia (A), and lemon (A) experiments to determine the viability of $G$. citricarpa in the lesions on fruit receiving different treatments. The number of lesions used depended on the number of symptomatic fruit available in each treatment. Usually between four and nine lesions were sampled, but as few as 2 and as many as 23 
lesions were sampled in some cases. For isolations, fruit were first wiped with tissue saturated with $70 \%$ ethanol and lesions were excised aseptically. Tissue pieces were surface-sterilized with $1 \% \mathrm{NaOCl}$ for 40 to $60 \mathrm{~s}$, rinsed twice with sterile distilled water, and blotted dry on sterilized paper. Two pieces per lesion from the flavedo, the outer pigmented layer of the peel, were plated on potato dextrose agar (PDA), and the plates were incubated in the dark for 7 to 8 days at $27^{\circ} \mathrm{C}$. Tissue pieces with typical Guignardia colonies were considered positive, and results were expressed as the percentage of positive isolations.

Data on the effect of field treatment, postharvest fungicide application, storage conditions, and time on the percentage of isolation of G. citricarpa was subjected to logistic analysis using PROC GENMOD in SAS (SAS Institute, Cary, NC). This procedure assumed a binomial distribution of the dependent variable and logit link function. Mean separations were made using individual contrasts $(P \leq 0.05)$ with no adjustment for multiple comparisons. An orthogonal polynomial contrast was used to examine the linear effect of time on percent isolation.

Effect of field incidence on postharvest development of CBS. Fruit free of symptoms were harvested from field fungicide trials to determine the relationship between the field incidence of CBS and percentage of asymptomatic fruit developing symptoms after harvest. Lots of 60 to 100 symptomless Valencia orange fruit each were collected arbitrarily from plots that had $75,48,20,7$, and $2 \%$ of the fruit affected by CBS. Fruit with $75 \%$ field incidence were selected from the control plots in Valencia (A), and those with $48 \%$ were selected from the control plots in
Valencia (B). Fruit with $20 \%$ field incidence were selected from plots sprayed with copper hydroxide (Champ $80 \mathrm{WP}$ at 3 $\mathrm{kg} / \mathrm{hl}$ ) on 15 September 2002, carbendazim (Carbendazim $50 \mathrm{SC}$ at $1.2 \mathrm{~kg} / \mathrm{hl}$ ) on 24 October 2002, copper hydroxide + mancozeb (Mancozeb 80 at 2.0 liters/hl) on 18 December 2002, trifloxystrobin (Flint 50 at $0.1 \mathrm{~kg} / \mathrm{hl})+$ copper hydroxide on 27 January 2003, and copper hydroxide + mancozeb on 22 March 2003. Fruit with 7.3\% field incidence were selected from plots sprayed on the same dates and rates as above, but using the following materials: 1) copper hydroxide, 2) pyraclostrobin (Comet at 0.2 liters/hl) + copper hydroxide, 3) no spray, 4) carbendazim, and 5) pyraclostrobin + copper hydroxide. Fruit with $1.8 \%$ field incidence were selected from plots sprayed on the same dates and rates as above, but with the following program: 1) copper hydroxide, 2) pyraclostrobin + copper hydroxide, 3) no spray, 4) carbendazim, and 5) carbendazim. Half of the trees in plots with 20 and $2 \%$ CBS incidence in the field were sprayed with carbendazim (Carbendazim $50 \mathrm{SC}$ ) at 15 $\mathrm{ml} /$ liter on 21 July 2004 and prior to harvest on 9 August 2004, to attempt to further reduce postharvest symptom development. All fruit received the same benomyl drench treatment used in the previous experiments. After harvest, all fruit were passed through the packinghouse, where they were treated with the commercial postharvest fungicide and waxed. Half of each fruit lot was stored at $8^{\circ} \mathrm{C}$ in the dark and the other half under ambient conditions as described in the previous experiments. CBS incidence was determined after 40 days of storage. The effect of storage treatment and field incidence on postharvest CBS incidence was evaluated using an analysis of covariance model that included postharvest storage treatment (refrigerated or ambient) as a fixed effect and the square of field incidence expressed as a percentage as a continuous independent variable. The interaction between these factors was also evaluated.

Survival of $G$. citricarpa in detached fruit and peel. Whole fruit or peel tissue with hard spot or false melanose symptoms were incubated under the following conditions to determine the ability of G. citricarpa to survive: (i) in a moist chamber maintained constantly wet, (ii) moistened every other day during the week and allowed to dry in between, and (iii) maintained dry in the laboratory at ambient temperature and humidity ( 18 to $25^{\circ} \mathrm{C}$ and 40 to $90 \% \mathrm{RH})$. Each replicate consisted of four fruit or peel pieces, and three replications were used for each treatment. After 7, 14,28 , and 40 days, four lesions were selected arbitrarily from the fruit or peel pieces in each replication. The peel surface was wiped with a tissue saturated with $70 \%$ ethanol, the lesions dissected from the fruit or peel tissue, surface-sterilized in $1 \% \mathrm{NaOCl}$ for 30 to $60 \mathrm{~s}$, rinsed thoroughly with sterile distilled water, and blotted dry. Each lesion was divided in half, and the two pieces were plated aseptically and onto PDA. Cultures were incubated at $27^{\circ} \mathrm{C}$ for 1 week, and the number of lesions with typical colonies of G. citricarpa was recorded. If either of the two tissue pieces yielded the pathogen, the lesion was recorded as positive. The number of positive isolations from the four lesions per replication was recorded. The experiment was conducted three times. The number of positive isolations from each of the four lesions in each replicate was subjected to analysis of variance without transformation. The significance of tissue type (peel versus whole fruit), mois-

Table 1. Incidence of postharvest symptoms of citrus black spot (CBS) on stored fruit that had received a preharvest CBS field control program versus none, a benomyl drench treatment immediately after harvest versus none, various packinghouse fungicide treatments, and that were stored at two temperatures ${ }^{\mathrm{w}}$

\begin{tabular}{|c|c|c|c|c|c|}
\hline \multirow[b]{2}{*}{ Factor } & \multicolumn{5}{|c|}{ CBS incidence (\%) } \\
\hline & Murcott & Valencia (A) & Valencia $(B)$ & Lemon (A) & Lemon (B) \\
\hline $\begin{array}{l}\text { Field treatment } \\
\text { No field treatment } \\
P^{\mathrm{y}}\end{array}$ & $\begin{array}{l}1.3 \mathrm{~b}^{\mathrm{x}} \\
10.7 \mathrm{a} \\
<0.0001\end{array}$ & $\begin{array}{l}7.9 \mathrm{~b} \\
41.7 \mathrm{a} \\
<0.0001\end{array}$ & $\begin{array}{l}- \\
- \\
-\end{array}$ & $\begin{array}{l}\quad 6.8 \mathrm{~b} \\
41.4 \mathrm{a} \\
<0.0001\end{array}$ & $\begin{array}{l}- \\
- \\
-\end{array}$ \\
\hline $\begin{array}{l}\text { Benomyl drench } \\
\text { No drench } \\
P\end{array}$ & $\begin{array}{l}5.9 \\
6.1 \\
0.79\end{array}$ & $\begin{array}{c}24.3 \\
25.2 \\
0.09\end{array}$ & $\begin{array}{c}13.0 \\
11.0 \\
0.64\end{array}$ & $\begin{array}{c}24.3 \\
25.0 \\
0.84\end{array}$ & $\begin{array}{l}- \\
- \\
-\end{array}$ \\
\hline $\begin{array}{l}8^{\circ} \mathrm{C} \\
\text { Ambient }\left(15-25^{\circ} \mathrm{C}\right) \\
P\end{array}$ & $\begin{array}{c}3.4 \mathrm{~b} \\
8.7 \mathrm{a} \\
<0.0001\end{array}$ & $\begin{array}{l}13.7 \mathrm{~b} \\
35.8 \mathrm{a} \\
<0.0001\end{array}$ & $\begin{array}{c}7.8 \mathrm{~b} \\
16.2 \mathrm{a} \\
0.005\end{array}$ & $\begin{array}{l}6.1 \mathrm{~b} \\
43.9 \mathrm{a} \\
<0.0001\end{array}$ & $\begin{array}{c}9.4 \mathrm{~b} \\
17.4 \mathrm{a} \\
0.04\end{array}$ \\
\hline $\begin{array}{l}\text { Postharvest fungicide } \\
\text { Wax only } \\
\text { Fludioxonil } \\
\text { Pyrimethanil } \\
\text { Pyrimethanil + imazalil } \\
\text { Commercial }^{\mathrm{z}}\end{array}$ & $\begin{array}{l}6.5 \\
7.7 \\
5.1 \\
5.5 \\
5.3 \\
0.97\end{array}$ & $\begin{array}{c}27.3 \\
26.6 \\
21.2 \\
24.9 \\
23.9 \\
0.53\end{array}$ & $\begin{array}{r}15.0 \\
8.7 \\
14.7 \\
13.1 \\
8.9 \\
0.23\end{array}$ & $\begin{array}{c}28.6 \\
26.1 \\
23.8 \\
22.4 \\
22.0 \\
0.13\end{array}$ & $\begin{array}{c}13.0 \\
16.0 \\
12.6 \\
15.0 \\
10.7 \\
0.83\end{array}$ \\
\hline
\end{tabular}

${ }^{\mathrm{w}}$ All fruit were symptomless at harvest.

${ }^{x}$ Mean separation within groups by Fisher's protected least significant difference, $P \leq 0.05$.

y Probability of $F$ greater than that observed for effect within analysis of variance model.

${ }^{\mathrm{z}}$ Commercial $=$ imazalil at $2,500 \mu \mathrm{g} / \mathrm{ml}$, thiabendazole at $5,000 \mu \mathrm{g} / \mathrm{ml}$, and 2,4-D at $500 \mu \mathrm{g} / \mathrm{ml}$. 
ture conditions, storage temperature, and storage time was determined by analysis of variance. Orthogonal polynomial contrasts were used to examine the linear effect of time on isolate recovery. Mean separations of treatments were made using Fisher's protected least significant difference test $(P \leq 0.05)$

\section{RESULTS}

Effect of field and postharvest fungicide applications and storage temperatures. Field treatments of fruit during the main infection period between September and January greatly reduced the incidence of CBS at harvest in all experiments where evaluated. In the Murcott, Valencia (A), and lemon (A) experiments, the incidence of fruit with symptoms in the nonsprayed plots was $76.8,79.6$, and $69.5 \%$, respectively. In plots receiving preharvest programs described above, the incidence was 6.8, 7.1, and $5.5 \%$ in the Murcott, Valencia (A), and lemon (A) experiments, respectively.

When symptomless fruit were harvested from these experiments and stored, the

Table 2. Isolation frequency of Guignardia citricarpa from symptomatic fruit with citrus black spot (CBS) that had received a preharvest CBS field control program versus none, a fungicide drench treatment immediately after harvest versus none, various packinghouse fungicide treatments, and that were stored at different temperatures

\begin{tabular}{lccc}
\hline & \multicolumn{3}{c}{ \% Isolation } \\
\cline { 2 - 4 } Factor & Murcott & Valencia (A) & Lemon $(\mathbf{A})$ \\
\hline Field treatment & $13.0 \mathrm{~b}^{\mathrm{y}}$ & $13.2 \mathrm{~b}$ & $7.2 \mathrm{~b}$ \\
No field treatment & $33.5 \mathrm{a}$ & $28.3 \mathrm{a}$ & $22.7 \mathrm{a}$ \\
$P^{\mathrm{z}}$ & $<0.001$ & $<0.001$ & $<0.001$ \\
Ambient $\left(15-25^{\circ} \mathrm{C}\right)$ & $27.1 \mathrm{a}$ & $11.8 \mathrm{~b}$ & $22.5 \mathrm{a}$ \\
$8^{\circ} \mathrm{C}$ & $18.4 \mathrm{~b}$ & $30.2 \mathrm{a}$ & $6.9 \mathrm{~b}$ \\
$P$ & 0.03 & $<0.001$ & $<0.001$ \\
Postharvest fungicide & & & \\
$\quad$ Wax only & $11.4 \mathrm{~b}$ & 22.9 & 15.5 \\
$\quad$ Fludioxonil & $31.7 \mathrm{a}$ & 19.1 & 17.7 \\
$\quad$ Pyrimethanil & $30.6 \mathrm{a}$ & 23.9 & 12.7 \\
$\quad$ Pyrimethanil + imazalil & $28.1 \mathrm{a}$ & 18.1 & 22.2 \\
$\quad$ Commercial & $20.1 \mathrm{ab}$ & 22.0 & 6.7 \\
$P$ & 0.004 & 0.54 & 0.15 \\
Storage time (days) & & & \\
$\quad 9$ & $39.9 \mathrm{a}$ & $15.1 \mathrm{~b}$ & $18.9 \mathrm{a}$ \\
$\quad 20$ & $23.5 \mathrm{~b}$ & $24.5 \mathrm{a}$ & $11.7 \mathrm{~b}$ \\
$\quad 49$ & $5.6 \mathrm{c}$ & $23.9 \mathrm{a}$ & $14.1 \mathrm{~b}$ \\
$P$ & $<0.001$ & 0.03 & 0.02 \\
Linear & $<0.001$ & 0.10 & 0.08 \\
\hline
\end{tabular}

${ }^{y}$ Mean separation within groups by single-degree-of-freedom contrasts, $P \leq 0.05$.

${ }^{\mathrm{z}}$ Probability $\chi^{2}$ greater than observed for effect within logistic model.

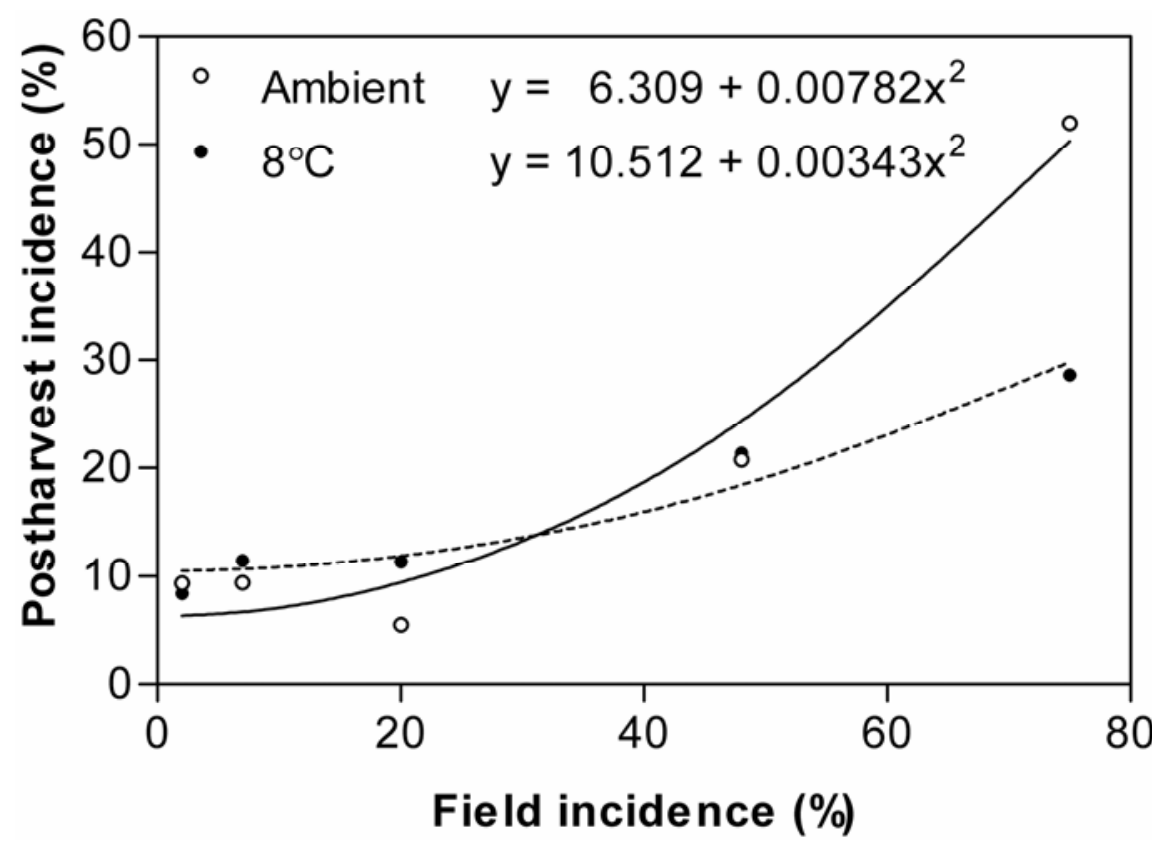

Fig. 1. Relationship of field incidence of citrus black spot to the development of symptoms postharvest when symptomless fruit were stored at $8^{\circ} \mathrm{C}$ or at ambient temperature $\left(15\right.$ to $\left.25^{\circ} \mathrm{C}\right)$; analysis of covariance $r^{2}=0.95$.

field treatment program significantly reduced postharvest disease incidence in all three experiments where it was utilized (Table 1). The application of benomyl as a drench immediately after harvest had no effect on the appearance of CBS in storage in any of the four experiments where that treatment was evaluated (Table 1). Storage of fruit at $8^{\circ} \mathrm{C}$ significantly reduced postharvest incidence of CBS compared with storage at ambient temperatures in all five experiments (Table 1). None of the four packinghouse fungicide treatments reduced the postharvest incidence of CBS compared with the wax only control in any of the five experiments (Table 1). Field fungicide treatment and storage temperature were the only factors that significantly affected the postharvest appearance of CBS. The only interaction among treatments that was significant $(P \leq 0.04)$ among the 21 interactions examined was between the field treatment and the packinghouse fungicide application, and that was observed only in the Murcott experiment.

The field fungicide application program significantly reduced the frequency of isolation of $G$. citricarpa from different types of CBS lesions that developed after harvest in all three experiments (Table 2). Storage of fruit at $8^{\circ} \mathrm{C}$ significantly reduced the isolation frequency in the Murcott and the lemon (A) experiments, but the opposite effect was observed in the Valencia (A) experiment. Application of fungicides to fruit postharvest had relatively little effect on the isolation frequency of $G$. citricarpa. No significant effect was observed in the Valencia (A) and the lemon (A) experiments, but isolation frequency was higher from fruit receiving fungicide treatments than from the wax only treatment in the Murcott experiment (Table 2). Storage time was a significant factor in the isolation frequency in the logistic analysis in all three experiments (Table 2). This effect was strongly linear in the Murcott experiment, but less so in the Valencia (A) and lemon (A) experiments. Isolation frequency declined with time in the Murcott and lemon (A) experiments, but not in the Valencia (A) experiment.

Effect of field incidence on postharvest appearance of CBS. When asymptomatic fruit were harvested from plots with different levels of CBS, postharvest incidence was related to field incidence (Fig. 1). The relationship between field and postharvest incidence was quadratic, and there was a significant interaction between the effects of field incidence and storage temperature with the slope of the curve being greater at ambient storage temperature. In lots of fruit with $20 \%$ field incidence, those that received a carbendazim application 3 weeks before harvest developed symptoms on $11.4 \%$ of the fruit after storage, whereas the fruit not receiving preharvest carbendazim had $6.4 \%$ 
symptomatic fruit. In lots of fruit with $2 \%$ field incidence, $8.4 \%$ of those receiving preharvest carbendazim developed symptoms on the fruit; whereas, in those not receiving a preharvest treatment, $6.2 \%$ were symptomatic after storage. The effect of preharvest application with carbendazim on postharvest development of CBS symptoms was not significant in either case.

Survival of $G$. citricarpa in detached whole fruit and detached peel. G. citricarpa was isolated from 20 to $40 \%$ of the lesions on whole fruit and peel stored under different conditions (Table 3). There was little difference between recovery from fruit or peel among the three experiments. Recovery was significantly higher from fruit than from peel only in the Valencia (A) experiment. There was no effect of moisture levels or storage temperature in any of the three tests (Table 3). In the analysis of variance, time was marginally significant $(P<0.10)$ in all three experiments (Table 3). Of 15 interactions examined, only one, temperature $\times$ time in the Valencia experiment, was significant. The effect of time of storage on survival tended to be more quadratic than linear. Isolation frequency was sometimes low initially, increased, and then eventually declined with time. In summary, none of the conditions evaluated greatly affected recovery of the pathogen. G. citricarpa could be isolated from affected fruit or peel at least through 40 days regardless of the storage conditions.

\section{DISCUSSION}

Postharvest development of CBS was most affected by utilization of a program of fungicide applications in the field during the season. These programs reduced the incidence of CBS at harvest and reduced postharvest symptom development by reducing the number of quiescent infections. Although field fungicide applications reduced incidence to low levels, they did not totally eliminate quiescent infections even when incidence was very low at harvest. In the only other study where management of postharvest CBS symptom development using preharvest spray programs was examined, Seberry et al. (20) concluded that preharvest copper fungicide applications had no effect on the postharvest development of symptoms.

As reported previously $(5,13)$, we found that cold storage reduced the postharvest incidence of CBS symptoms on the fruit. Low temperatures probably slow fungal growth and symptom development. If fruit were moved to higher temperatures after storage or shipment, symptoms would probably develop rapidly. Once the quiescent infections on the fruit are established, it appears to be difficult to prevent symptom development after harvest.

Nam et al. (17) found that preharvest sprays of benzimidazole fungicides delayed expression of CBS symptoms, but in our study, neither preharvest application nor postharvest drench treatment with benomyl affected the postharvest appearance of CBS symptoms. Kotzé (12) found that a single benomyl application late in the season, but still well before harvest, was highly effective for CBS control. In some cases, others have found positive effects of waxing or postharvest fungicide applications in reducing CBS development $(11,20,23)$. In the case of the waxes $(20,23)$, the effects noted were rather small but still significant, and Korf et al. (11) found that postharvest treatments prevented secondary infection by conidia produced on symptomatic fruit. Other investigators have found little benefit to postharvest fungicide applications $(1,2)$. None of the treatments applied near harvest that we tested was effective in reducing the disease development. Based on the previous results and this study, we conclude that currently available treatments applied shortly before or after harvest will not greatly affect the appearance of CBS symptoms.

The postharvest development of CBS on fruit is of concern for marketing. However, the viability of $G$. citricarpa on fruit or remains of fruit is of greater concern for introduction of the pathogen. The results of our isolations from fruit receiving various treatments were not always consistent. The field fungicide program was effective in reducing disease incidence after harvest and also reduced the frequency of successful isolations once the symptoms developed. This is difficult to explain since all isolations were made from symptomatic fruit and it is not obvious why the fungus should be less viable. Cold storage effects were ambiguous and usually decreased but sometimes increased the viability of the pathogen.

Postharvest fungicide application usually had no effect, but in the one case where it did, fungicide treatment increased recovery. This may have been due to fungicidal suppression of competing fungi rather than any direct effect. Korf et al. (11) reported that treatment with guazatine or imazalil reduced the viability of the pathogen, but imazalil did not have that effect in our study. Of the fungicides utilized in our test, imazalil and thiabendazole are highly inhibitory to conidial germination and appressoria formation at 2 to $5 \mu \mathrm{g} / \mathrm{ml}$ (11). The viability of the pathogen tended to decline with time of fruit storage. However, G. citricarpa was still viable long after the fruit had passed the stage where it would be marketable. Despite some variable results, it appears that $G$. citricarpa remains viable in fruit receiving a wide range of different treatments.

Also of concern for potential introduction of $G$. citricarpa into new areas is the fate of the pathogen once it arrives at the consumer. Thus, we evaluated the viability of the fungus in simulated conditions if the whole fruit or peel were discarded. Under all of the conditions that we tested, $G$. citricarpa was still viable as long as the lesion was intact on peel or fruit. Viability declined with time, but the fungus was still recoverable until the plant tissue was completely decomposed by other organisms. However, only pycnidia of the pathogen were produced on these tissues, so the

Table 3. Isolation frequency of Guignardia citricarpa from symptomatic fruit or peel stored under different moisture conditions, temperatures, and for different times

\begin{tabular}{|c|c|c|c|}
\hline \multirow[b]{2}{*}{ Factor } & \multicolumn{3}{|c|}{ Fruit } \\
\hline & Murcott & Valencia (A) & Lemon (A) \\
\hline \multicolumn{4}{|l|}{ Tissue } \\
\hline Peel & 25.0 & $25.0 \mathrm{~b}^{\mathrm{x}}$ & 24.3 \\
\hline Fruit & 22.5 & $33.3 \mathrm{a}$ & 32.8 \\
\hline$P^{\mathrm{y}}$ & 0.63 & 0.05 & 0.22 \\
\hline \multicolumn{4}{|l|}{ Humidity } \\
\hline Saturated & 21.8 & 26.3 & 24.0 \\
\hline Moist & 24.3 & 27.0 & 30.3 \\
\hline Dry & 25.5 & 34.5 & 31.3 \\
\hline$P$ & 0.83 & 0.22 & 0.64 \\
\hline \multicolumn{4}{|l|}{ Temperature } \\
\hline $8^{\circ} \mathrm{C}$ & 25.3 & 28.5 & $\mathrm{nd}^{\mathrm{z}}$ \\
\hline Ambient $\left(18-25^{\circ} \mathrm{C}\right)$ & 23.3 & 29.8 & nd \\
\hline$P$ & 0.84 & 0.77 & nd \\
\hline \multicolumn{4}{|l|}{ Time } \\
\hline 7 days & 29.3 & 28.5 & $16.8 \mathrm{c}$ \\
\hline 14 days & 29.5 & 38.0 & $40.3 \mathrm{a}$ \\
\hline 28 days & 16.8 & 30.5 & $36.0 \mathrm{ab}$ \\
\hline 40 days & 20.0 & 19.5 & $21.5 \mathrm{bc}$ \\
\hline$P$ & 0.09 & 0.07 & 0.04 \\
\hline Linear & 0.11 & 0.84 & 0.70 \\
\hline Quadratic & 0.20 & 0.18 & 0.17 \\
\hline
\end{tabular}

x Mean separation within groups by Fisher's protected least significant difference $P \leq 0.05$.

y Probability $F$ greater than that observed for effect within analysis of variance model.

${ }^{\mathrm{z}}$ nd $=$ not done. 
possibility of dispersal from this source would be relatively low.

The most effective means of reducing CBS development on fruit postharvest is by use of a highly effective control program during the summer when most of the infections occur. Storage and shipment of the fruit in the dark at cool temperatures slows symptom development and will help reduce the amount of fruit discarded at the destination. Postharvest fungicide treatments are unlikely to be beneficial.

We do not consider commercial fruit to be a high risk means for introduction of $G$. citricarpa into new areas when compared with contraband vegetative material. Some pycnidiospores may be produced on fruit with hard spot lesions, but they are splashdispersed and would require the presence of susceptible tissue in close proximity to the source. Nevertheless, G. citricarpa remains viable under a wide range of conditions in fruit peel. According to our results, if CBS symptoms are present, it is highly likely that the pathogen is alive and has some potential to spread.

\section{LITERATURE CITED}

1. Andrade, A. G., Bellotte, J. A. M., Barbosa, C. R. C., Correa, E. B., Baldassari, R. B., and Goes, A. 2001. Efeito de eletrochoque combinado com thiabendazole e $\mathrm{KCl}$ e temperatura de armazenamento no controle de Guignardia citricarpa em frutos cítricos na fase de póscolheita. Fitopatol. Bras. 26(Supl.):396.

2. Andrade, A. G., Bellotte, J. A. M., Barbosa, C. R. C., Correa, E. B., Baldassari, R. B., and Goes, A. 2001. Efeito de choque térmico combinado com thiabendazole e glicerol no controle de Guignardia citricarpa em frutos cítricos na fase pós-colheita. Fitopatol. Bras. 26(Supl.):396-397.

3. Baayen, R. P., Bonants, P. J. M., Verkley, G., Carroll, G. C., van der Aa, H. A., de Weerdt,
M., van Brouwershaven, I. R., Schutte, G. C., Maccheroni, W., Jr., Glienke de Blanco, C., and Azevedo, J. L. 2002. Nonpathogenic isolates of the citrus black spot fungus, Guignardia citricarpa, identified as a cosmopolitan endophyte of woody plants, G. mangiferae (Phyllosticta capitalensis). Phytopathology 92:464-477.

4. Bonants, P. J. M., Carroll, G. C., DeWeerdt, M., Van Brouwershaven, I. R., and Baayen, R. P. 2003. Development and validation of a fast PCR-based detection method for pathogenic isolates of the citrus black spot fungus, Guignardia citricarpa. Eur. J. Plant Pathol. 109:503-513.

5. Brodrick, H. T. 1975. Light and temperature effects on symptom development of citrus black spot disease. Citrus Series H. 1.1.1(a). Farming in South Africa. Dep. Agric. Tech. Serv., Pretoria.

6. de Goes, A. 2002. Efeito da combinação de fungicidas sistêmicos e protetores no controle da mancha preta dos frutos cítricos causada por Guignardia citricarpa. Summa Phytopathol. 28:9-13.

7. Garrán, S. M. 1996. Citrus black spot in the Northeast of Entre Rios: Etiology, epidemiology and control. Proc. Int. Soc. Citricult. 1:466-470.

8. Huang, C. S., and Chang, S. L. 1972. Leaf infection with citrus black spot and perithecial development in relation to ascospore discharge of Guignardia citricarpa Kiely. J. Taiwan Agric. Res. 21:256-263.

9. Kiely, T. B. 1948. Preliminary studies on Guignardia citricarpa n. sp., the ascigerous stage of Phoma citricarpa McAlp., and its relation to blackspot of citrus. Proc. Linn. Soc. N.S.W. 73:249-292.

10. Kiely, T. B. 1950. Control and epiphytology of black spot of citrus. N.S.W. Dep. Agric. Sci. Bull. 71:1-66.

11. Korf, H. J. G., Schuttle, G. C., and Kotzé, J. M. 2001. Effect of packinghouse procedures of the viability of Phyllosticta citricarpa, anamorph of the black spot pathogen. Afr. Plant Prot. 7:103-109.

12. Kotzé, J. M. 1981. Epidemiology and control of citrus black spot in South Africa. Plant Dis.
65:945-950.

13. Kotzé, J. M. 2000. Black spot. Pages 23-25 in: Compendium of Citrus Diseases. L. W Timmer, S. M. Garnsey, and J. H. Graham, eds. American Phytopathological Society, St. Paul, MN.

14. Lee, Y. S., and Huang, C. S. 1973. Effect of climatic factors on the development and discharge of ascospores of the citrus black spot fungus. J. Taiwan Agric. Res. 22:135-144.

15. McOnie, K. C. 1964. Source of inoculum of Guignardia citricarpa, the citrus black spot pathogen. Phytopathology 54:64-67.

16. McOnie, K. C. 1967. Germination and infection of citrus by ascospores of Guignardia $\mathrm{ci}$ tricarpa in relation to control of black spot. Phytopathology 57:743-746.

17. Nam, K. W., Kweon, H. M., and Song, N. H. 1993. Storage of Satsuma mandarin. I. Storability of Satsuma mandarin influenced by thiophanate-methyl treatment and mechanical injuries. J. Korean Soc. Hortic. Sci. 34:279284.

18. Peres, N. A. R., and Timmer, L. W. 2003 Citrus black spot caused by Guignardia citricarpa. CABI Crop Protection Compendium, CAB International, Oxford, UK

19. Robbs, C. F., and Bittencourt, A. M. 1995. A mancha preta dos frutos: um dos fatores limitantes à produção citrícola do estado do Rio de Janeiro. Comunicado Técnico, EMBRAPA CTAAA 19:1-5.

20. Seberry, J. A., Leggo, D., and Kiely, T. B. 1967. Effect of skin coatings on the development of black spot in stored Valencia oranges. Aust. J. Exp. Agric. Anim. Husb. 7:593-600.

21. Timmer, L. W. 1999. Diseases of fruit and foliage. Pages 107-115 in: Citrus Health Management. L. W Timmer and L. W. Duncan, eds American Phytopathological Society, St. Paul, $\mathrm{MN}$.

22. Timossi, A. J., de Goes, A., Kupper, K. C., Baldassari, R. B., and dos Reis, R. F. 2003. Influência da temperatura e da luminosidade no desenvolvimento de Guignardia citricarpa, agente causal da mancha preta dos frutos citricos. Fitopatol. Bras. 28:489-494.

23. Wild, B. L. 1981. The effects of waxing citrus fruit. Rural Newsl. 79:14-19. 